\title{
Study of Helicobacter pylori genotype status in cows, sheep, goats and human beings
}

\author{
Hassan Momtaz ${ }^{1}$, Hossein Dabiri ${ }^{2}$, Negar Souod ${ }^{3 *}$ and Mohsen Gholami ${ }^{4}$
}

\begin{abstract}
Background: Helicobacter pylori is one of the most controversial bacteria in the world causing diverse gastrointestinal diseases. The transmission way of this bacterium still remains unknown. The possibility of zoonotic transmission of $\mathrm{H}$. pylori has been suggested, but is not proven in nonprimate reservoirs. In the current survey, we investigate the presence of $H$. pylori in cow, sheep and goat stomach, determine the bacterium virulence factors and finally compare the human $\mathrm{H}$. pylori virulence factors and animals in order to examine whether H. pylori might be transmitted from these animals to human beings.

Methods: This cross- sectional study was performed on 800 gastric biopsy specimens of cows, sheep, goats and human beings. The PCR assays was performed to detection of H. pylori, vacA and cagA genes. The PCR products of Ruminant's samples with positive H. pylori were subjected to DNA sequencing analysis. Statistical tests were applied for data analysis.

Results: Overall 6 (3\%) cows, 32 (16\%) sheep and 164 (82\%) human beings specimens were confirmed to be H. pylori positive; however we were not able to detect this bacterium in all 200 goat samples. The vacA s1a/m $1 a$ was the predominant $H$. pylori genotype in all three kinds of studied population. There was $3.4-8.4 \%$ variability and 92.9-98.5\% homology between sheep and human samples.
\end{abstract}

Conclusions: Considering the high sequence homology among DNA of H. pylori isolated from sheep and human, our data suggest that sheep may act as a reservoir for $\mathrm{H}$. pylori and in the some extent share the ancestral host for the bacteria with human.

Keywords: Helicobacter pylori, Virulence genes, Cow, Sheep, Goat, Human being

\section{Background}

Helicobacter pylori is a gram negative, spiral shaped bacterium which its main reservoir is humans, particularly the human stomach. It colonizes most of the population, making it one of the most controversial bacteria in the world that cause gastritis, peptic ulcer, duodenal ulcer, lymphoma and gastric cancer [1].

According to the reports the main routs of infection has not been clarified yet [2]. However it is likely that $H$. pylori infection occurs during childhood or adolescence both in developing and developed countries [3] and its transmission occurs by person to person, either by fecaloral or oral-oral routes [4].The possibility of zoonotic transmission of $H$. pylori has been suggested, but is not

\footnotetext{
* Correspondence: negarsouod@yahoo.com

${ }^{3}$ Young Researchers and Elite club, Central Tehran Branch, Islamic Azad University, P.O.Box: 13185-768, Tehran, Iran

Full list of author information is available at the end of the article
}

proven in nonprimate reservoirs [4]. Some reports indicated that there is a high prevalence of antibody against this bacterium in veterinarians, butchers and slaughters rather than other people, so it suggests that $H$. pylori might be transmitted from animals to human $[5,6]$. Recently some researchers have been isolated $H$. pylori from cow, sheep, camel, pigs and dogs milk $[7,8]$. Therefore, it seems that these animals can be a reservoir of this bacterium. The severity of clinical manifestations varies depends on several factors such as host genetic, immune system, bacterial load and virulence factors [9]. This bacterium has several virulence factor genes which are generally classified into three categories: I) strain-specific genes, such as cag pathogenesity island (PAI) and genes located in plasticity island region (e.g. jhp0947 and dupA genes), which are present in only some $H$. pylori strains. II) phase-variable genes which change during different 
growth conditions. Based on comparison of three completed genomes of $H$. pylori, six genes encoding outermembrane proteins (babB, oipA, hopZ $s a b A, s a b B$ and $b a b C)$ are supposed to have phase variation. III) The genes with polymorphisms, for instance, specific vacA genotypes have been associated with different clinical outcomes [10]. The cag pathogenicity island (PAI) which belongs to the first category, encodes a type IV secretion system [2,3]. The $\operatorname{cagA}$ gene is located in the end of the cag PAI and has been proposed as a marker for the cagPAI. Different type of the $\operatorname{cagA}$ gene in some region is associated with diverse clinical outcomes; for instance cagAla in East Asian Strains, is associated with more severe clinical manifestations than the absence of the gene [11]. The other important virulence factor of $H$. pylori is a vacuolating cytotoxin (VacA), which belongs to the last category and is associated with injury to epithelial cells. The vacA gene is present in virtually all strains of $H$. pylori but it is polymorphic, comprising variable signal regions (type $s 1$ or $s 2$ ) and mid-regions (type $m 1$ or $m 2$ ). Type $s 1 / m 1 v a c A$ contribute with more epithelial cell damage rather than type $s 1 / m 2$, whereas type $s 2 / m 2$ and the rare $s 2 / m 1$ are supposed to be non-toxic due to the presence of a short 12-residue hydrophilic extension on the $s 2$ form [12,13]. The s-region is classified into $s 1$ and $s 2$ types and the m-region into $m 1$ and $m 2$ types. The $s 1$ type is further subtyped into $s 1 a, s 1 b$ and $s 1 c$ subtypes, and the $m 1$ into $m 1 a$ and $m 1 b$ subtypes. The mosaic combination of $\mathrm{s}$ and m-region allelic types determines the particular cytotoxin and, consequently, the pathogenicity of the bacterium [2,14].

In the current survey, we investigated the presence of H. pylori in cow, sheep and goat stomach, as well as bacterium virulence factors distribution among human and other studied population.

\section{Methods}

\section{Population and sampling}

Over all 800 samples; 200 from human and 600 from ruminant were included in the current study. In the ruminants group, over all 600 healthy domestic animals; 200 cows, 200 sheep and 200 goats referring for Zarrinshahr slaughterhouse in Isfahan, center of Iran, during February to August of 2012 were selected randomly. Considering sterile conditions, the sample from the rumen in size of $2 \mathrm{~mm}$ to $3 \mathrm{~mm}$ was obtained immediately after slaughtering. Samples were placed in $0.1 \mathrm{ml}$ of sterile saline solution and were transported rapidly to the laboratory. The histological examinations were performed by the specialized veterinarians of Shahrekord Azad University. For analysis of $H$. pylori DNA from human origin, regardless to career of patients, two hundred patients with dyspepsia symptoms referring to gastroenterology department of Hajar Hospital Shahrekord, Iran, from December 2011 to April 2012 were selected and gastric biopsies from antrum were obtained during endoscopy by endoscopist. All patients provided written informed consent prior to endoscopy. All the specimens were placed in $0.1 \mathrm{ml}$ of sterile saline solution and were transported to the laboratory immediately and were stored at $-70^{\circ} \mathrm{C}$ until further investigation.

\section{DNA analysis}

From all of biopsy specimens, DNA was extracted by using Genomic DNA purification kit (DNP ${ }^{\mathrm{rm}}$, CinnaGen, Iran) considering sterile condition according to manufacture recommendations. The $H$. pylori presence in studied samples was detected by PCR method using housekeeping gene; $\operatorname{glm} M$ gene as a target gene. Due to low sensitivity and difficulty of $H$. pylori culture particularly from animal sources, the samples were not cultured. The primers sequences for $g \operatorname{lm} M$ gene amplification were as follows: GlmM-F (5'- GCTTACTTTCTAACACT AACGCGC-3') and GlmM-R (5' - GGATAAGCTTTTA GGGGTGTTAGGGG-3') [2]. Primers were used for PCR assays of $v a c A$ allels and cagA genes has been described before [15,16]. DNA samples H. pylori (D0008, Genekam, Germany) were used as positive control of cagA and vacA genes, and sterile distilled water was used as negative control. PCR was done in $20 \mu \mathrm{L}$ (for $\operatorname{glm} M$ ) or $25 \mu \mathrm{L}$ (for vacA and $\operatorname{cag} A$ ) of total reaction volume containing $1.5 \mathrm{mM} \mathrm{MgCl}_{2}$ (2.0 mM for cagA), $50 \mathrm{mM} \mathrm{KCl,} 10 \mathrm{mM}$ Tris- $\mathrm{HCl}$ (pH 9.0), 0.1\% Triton X-100, $200 \mu \mathrm{M}$ dNTPs each (Fermentas), $0.4 \mu \mathrm{M}$ primers, $0.3 \mathrm{U}$ of Taq DNA polymerase (Fermentas), and $2 \mu \mathrm{L}(40-260 \mathrm{ng} / \mu \mathrm{L})$ of DNA. PCR was performed in a DNA Thermal Cycler (Eppendrof Mastercycler 5330, Eppendorf-Nethel-Hinz GmbH, Hamburg, Germany), with 40 cycles for GlmM primer and 35 cycles for $v a c A$ and cagA primers. Each cycle consisted of denaturation at $95^{\circ} \mathrm{C} / 45$ seconds; annealing at $59^{\circ} \mathrm{C} / 30$ seconds for $\operatorname{glm} M, 52^{\circ} \mathrm{C} / 45$ seconds for $v a c A$, and $58^{\circ} \mathrm{C} / 45$ seconds for $\operatorname{cag} A$; and extension at $72^{\circ} \mathrm{C} / 45$ seconds [16]. There was another longer extension of 6 minute at $72^{\circ} \mathrm{C}$. PCR products were visualized by electrophoresis in $1 \%$ agarose gel, were stained with ethidium bromide, and were examined under ultraviolet illumination.

\section{DNA sequencing analysis}

DNA sequencing analysis was performed on $6 \mathrm{H}$. pylori positive sample; 3 samples from cows and 3 samples from sheep which were selected randomly. Due to limitations we were not able to do sequence on all positive samples for $\operatorname{glm} M$ gene. For this purpose the DNA extraction was done by the same method as mentioned before for PCR. The amplified 296-bp PCR products ( $g l m M$ gene) from 6 positive samples were purified with High pure PCR product purification kit (Roche Applied 
Science), according to manufacturer's recommendations. Single DNA strands were sequenced with ABI $3730 \mathrm{XL}$ device and Sanger sequencing method (Macrogen, Korea).

After the sequence of 6 isolates were trimmed by using Edit View v.1.0.1 (Applied Bioscience, Australia), the sequences of 8 isolate with human source, which has been stored in GenBank with accession numbers: FN598874, CP003476, DQ462665, M60398, NC017361, GU445163, DQ141576, AB664954 were aligned separately against obtained animal isolate sequences using the Clustal W v1.81 in order to obtain a consensus sequence for the gene, $\operatorname{glm} M$ (H. pylori ureC). BioEdit Pakage V.7.0.4.1 was used to edit all sequence alignments. The nucleotide sequences of the Iranian ruminant $H$. pylori glmM (ureC) gene was compared with the correspond sequences reported from other regions via NCBI. By using Njplot software and 1000 bootstrap replicate, an unrooted dendrogramme was constructed.

\section{Ethical considerations}

The present study was accepted by the ethical committee of the Hajar Hospital of Shahrekord, Iran and Microbiology and Infectious Diseases Center of the Islamic Azad University of Shahrekord Branch, Iran. Written informed consent was obtained from all of the study patients or their parents.

\section{Results}

Totally 600 ruminants and 200 human gastric samples were collected in the current investigation. According to clinical and histopathological examinations, 10 cows and 2 sheep had moderate gastric inflammations while all goats were healthy, however none of the animals showed clinical manifestations. Based on gastroendoscopic and histopathologic finding, out of 200 human biopsy specimens, sixteen patients (11.8\%) had gastric ulcers, 22 (16.2\%) had duodenal ulcers, 194 (97.5\%) had chronic gastritis and 3 (2.2\%) had gastric cancer. Among 200 cow samples and 200 sheep samples, 6 (3\%) and 32 (16\%) were confirmed to be $H$. pylori positive; however, we were not able to find any H. pylori in goat samples. Out of 200 humans samples, 164 (82\%) were infected with this bacterium.

When we came to analyze the cagA gene in the positive samples, out of 6 cow, 32 sheep and 164 human samples, positive for $H$. pylori, 4 (66.66\%), 24 (75\%) and 151 (92.08\%) were cagA-positive respectively, however the cagA gene frequency among studied cow, sheep and human isolates was not statically significant $(\mathrm{p}=0.7)$.In case of the $v a c A$ gene alleles, according to cow specimen results, the frequency of $v a c A s 1 a, s 1 b, m 1 a$ and $m 2$ were 5 (83.33\%), 1 (16.66\%), 2 (33.33\%) and $4(66.66 \%)$ respectively. We were not able to detect $v a c A s 1 c, s 2$, and $m 1 b$ in the cows' population. The frequency of $v a c A$ $s 1 a, s 1 b, s 2, m 1 a$ and $m 2$ were 16 (50\%), 11 (34.37\%), 5 (15.66\%), 14 (43.75\%) and $18(56.25 \%)$ respectively in sheep's population. The $s 1 c$ and $m 1 b$ did not amplify any band in PCR assay for sheep samples (Table 1). As it was indicated in Table 1, in isolates from human samples, 79 (48.17\%) s1a, 21 (12.80\%) s1b, 35 (21.34\%) s1c, $29(17.68 \%) s 2$ were observed while for $v a c A \mathrm{~m}$ region, 52 (31.70\%), 15 (9.14\%) and 97 (59.14\%) isolates showed $m 1 a, m 1 b$ and $m 2$ genotype respectively. There was a statistically significant differences in prevalence of the $s 1 b$ allele among human beings and cows isolates $(P=0.025)$ as well as $s 1 a / m 2$ genotypes among human beings and sheep strains $(P=0.04)$. There was no statically significant relation between genotypes of $H$. pylori recovered from cows compare to sheep $(P=0.81)$ (Table 2). The nucleotide sequences of $H$. pylori glm $M$ gene, obtained from 6 Iranian ruminants; 3 cows and 3 sheep were compared with those from the known human reference sequences obtained from the GenBank nucleotide sequence database (8 sequences corresponding to $H$. pylori). The nucleotide sequence analyses showed a variability of $0.7-1.4 \%$ for the ure $C$ gene between sheep and cows samples (Table 3 ) and variations was consisted only in nucleotide sub-situation. Frame shift, deletion, insertion and nonsense mutations were not observed. When we compared the sequences of the $u r e C$ gene in sheep and human $H$. pylori isolates; there was $3.4-8.4 \%$ variability and $92.9-98.5 \%$ homology. The greatest sequence similarity $(98.5 \%$,) was found between H. pylori isolates of Iranian sheep and German human (FN598874), while the lowest relationship (91.6\%) between Iranian cow ureC sequence and South Africa (NC017361) was observed (Figure 1).

\section{Discussion}

Human is known as the main host of $H$. pylori; however the histopathology of this bacterium is in contrasts with many other gastric Helicobacter spp. In which their natural host response against bacteria involve mild or even no inflammatory response [4], so it is possible that $H$. pylori has originated from another mammalian host in the distant past [17]. In the current survey we evaluated whether cow, sheep and goat can be the original host of this bacterium. In order to achieve this goal we collected 600 gastric specimens from healthy cows, sheep, goats and 200 gastric biopsy from human with dyspepsia in west of Iran where the prevalence of $H$. pylori is higher than 70\% [18]. In our investigation, the prevalence of $H$. pylori in cows and sheep's population was $3 \%$ and $16 \%$ respectively, we were not able to detect it in goat's gastric tissue samples whereas the Italian survey on 400 milk samples by nested PCR assay, indicated that the prevalence of this bacterium in cow, sheep and goat populations were 50\%, 33\% and $25.6 \%$ respectively [8]. Scandinavian researchers found H. pylori in $60 \%$ of 38 sheep gastric tissue [4]. Also 
Table 1 The frequency of cagA and vacA alleles in Helicobacter pyloriof ruminants and human samples

\begin{tabular}{|c|c|c|c|c|c|c|c|c|}
\hline Positive samples & $\operatorname{cag} A$ & s1a & $s 1 b$ & s1c & s2 & $m 1 a$ & $m 1 b$ & $m 2$ \\
\hline Cow & 4 & 5 & 1 & 0 & 0 & 2 & 0 & 4 \\
\hline $6(3 \%)$ & $(66.66 \%)$ & $(83.33 \%)$ & $(16.66 \%)$ & & & (33.33\%) & & $(66.66 \%)$ \\
\hline Sheep & 24 & 16 & 11 & 0 & 5 & 14 & 0 & 18 \\
\hline $32(16 \%)$ & $(75 \%)$ & (50\%) & (34.37\%) & & $(15.62 \%)$ & $(43.75 \%)$ & & $(56.25 \%)$ \\
\hline Human & 151 & 79 & 21 & 35 & 29 & 52 & 15 & 97 \\
\hline $164(82 \%)$ & $(92.08 \%)$ & $(48.17 \%)$ & $(12.80 \%)$ & $(21.34 \%)$ & $(17.68 \%)$ & (31.70\%) & (9.14\%) & (59.14\%) \\
\hline
\end{tabular}

Rahimi and Kheirabadi declared $H$. pylori existed in $12.2 \%$ of sheep, $8.7 \%$ of goat and $14.1 \%$ of cow milk by PCR method [19]. In the other study which was conducted in Japan, $H$. pylori was found in $72.2 \%$ of cow raw milk specimens [20]. The diversity of $H$. pylori frequency in various hosts and regions may relate to animal, microbe and environmental factors. The prevalence of this bacterium in Iranian patients was $82 \%$ which is similar to previous reports from Iran and also Japan, South America, Turkey and Pakistan where more than $80 \%$ of dyspepsia patients were $H$. pylori positive, however in Scandinavia and England the prevalence ranges between 20\% to $40 \%$ $[21,22]$. According to our results, screening of goats' stomach for $H$. pylori was negative which is in accordance with Gueneau et al. study in 2003 in which they failed to detect H.pylori in studied goats [23]. This finding may support by two possible reasons: Ones that goats are an exception among ruminants in having particular natural mechanisms of resistance to this bacterium. Another hypothesis is that some other microorganisms like Candidatus $H$. bovis may colonize the goat's stomach and establish the extent of the resistance of goats to the super infection with H. pylori [23]. H. pylori strains with the cagA gene is supposed to be more virulent rather than cagA-negative strains [12] however this is not constant [2]. The prevalence of cagA-positive $H$. pylori varies from one geographic region to another, e.g., 97\% in Korea, 94\% in Malaysia, $90 \%$ in China, $78 \%$ in Turkey, 53\% in Kuwait, 85\% North America and 65\% in Slovenia [14,24-27]. In the current study cagA gene was found in $92 \%$ of Iranian populations which is in accordance with previous local report [18]. Since the most of $H$. pylori isolated from human samples regardless to clinical outcomes harbor the cagA gene $(P>0.05)$, thereby as it was declared previously, our finding did not support the role of the cagA as predictive marker for increased virulence feature of $H$. pylori in Iranian dyspepsia patients [1]. The cagA gene was found in 66\%, 75\% of cow and sheep populations respectively, which was not studied on animals' samples yet. There was no statically meaningful difference in status of the cagA in human and animal samples, which may reflect that all $H$. pylori recovered from human and animals have same ancestors. According to our results for the $v a c A$, all of our samples with positive PCR for $H$. pylori, irrespective to source of strains was positive for vacA. Although Dore et al. [4] in 2001 detected $v a c A$ gene in $60.3 \%$ and $7.9 \%$ of H. pylori strains isolated from sheep tissue and sheep milk samples respectively; now it is supposed that all $H$. pylori strains should possess the vacA gene, as it was supported by many studies around the world $[12,26,27]$. The $v a c A s 1 a / m 2$ were predominant $v a c A$ alles among all three studied population including human, cow and sheep.

Based on statistical analyses, there was a significant correlation between $s 1 a / m 2$ genotype of $H$. pylori in sheep and human beings. Also s1a allele was significantly prevalent among cow and human. To our knowledge, this is the first comparison study of $H$ pylori DNA sequence among specimens from cow, sheep and human in Middle East. As it was shown in Table 3 there was a high DNA sequence homology between $H$. pylori strains of sheep and human however this homology was low between cows

Table 2 The frequency of vacA genotypes in Helicobacter pylori of ruminants and human samples

\begin{tabular}{|c|c|c|c|c|c|c|c|c|c|c|c|c|}
\hline Positive samples & $s 1 a / m 1 a$ & $s 1 a / m 1 b$ & $\mathrm{~s} 1 \mathrm{a} / \mathrm{m} 2$ & $s 1 b / m 1 a$ & $s 1 b / m 1 b$ & $s 1 b / m 2$ & $s 1 c / m 1 a$ & $s 1 c / m 1 b$ & $s 1 c / m 2$ & $s 2 / m 1 a$ & $s 2 / m 1 b$ & $s 2 / m 2$ \\
\hline Cow & 2 & 0 & 3 & 0 & 0 & 1 & 0 & 0 & 0 & 0 & 0 & 0 \\
\hline $6(3 \%)$ & (33.33\%) & & $(50 \%)$ & & & $(16.66 \%)$ & & & & & & \\
\hline Sheep & 6 & 0 & 10 & 5 & 0 & 6 & 0 & 0 & 0 & 1 & 0 & 4 \\
\hline $32(16 \%)$ & $(18.75 \%)$ & & $(31.25 \%)$ & (15.62\%) & & $(18.75 \%)$ & & & & $(3.12 \%)$ & & $(12.5 \%)$ \\
\hline Human & 27 & 8 & 45 & 7 & 5 & 10 & 12 & 4 & 18 & 6 & 0 & 22 \\
\hline $164(82 \%)$ & $(16.46 \%)$ & $(4.87 \%)$ & $(27.43 \%)$ & $(4.26 \%)$ & (3.04\%) & (6.09\%) & (7.31\%) & $(2.43 \%)$ & (10.97\%) & (3.65\%) & & $(13.41 \%)$ \\
\hline
\end{tabular}


Table 3 Sequence identity matrix of partial ureC gene of Iranian ruminant Helicobacter pylori in comparison with 8 known human reference sequences

\begin{tabular}{|c|c|c|c|c|c|c|c|c|c|c|c|c|c|c|}
\hline Seq & Cow-1 & Cow-2 & Cow-3 & Sheep-1 & Sheep-2 & Sheep-3 & $\begin{array}{c}\text { FN598874- } \\
\text { Germany }\end{array}$ & $\begin{array}{l}\text { CP003476- } \\
\text { USA }\end{array}$ & $\begin{array}{l}\text { DQ462665- } \\
\text { Iran }\end{array}$ & $\begin{array}{l}\text { GU445163- } \\
\text { Iran }\end{array}$ & $\begin{array}{l}\text { M60398- } \\
\text { France }\end{array}$ & $\begin{array}{c}\text { NC017361-S } \\
\text { Africa }\end{array}$ & $\begin{array}{l}\text { DQ141576- } \\
\text { China }\end{array}$ & $\begin{array}{c}\text { AB664954 } \\
\text { Japan }\end{array}$ \\
\hline Cow-1 & ID & 0.999 & 1 & 0.989 & 0.987 & 0.991 & 0.953 & 0.962 & 0.932 & 0.941 & 0.928 & 0.920 & 0.926 & 0.926 \\
\hline Cow-2 & 0.999 & ID & 0.999 & 0.987 & 0.988 & 0.986 & 0.950 & 0.966 & 0.936 & 0.940 & 0.929 & 0.918 & 0.924 & 0.923 \\
\hline Cow-3 & 1 & 0.999 & ID & 0.992 & 0.986 & 0.993 & 0.927 & 0.964 & 0.932 & 0.944 & 0.930 & 0.916 & 0.922 & 0.923 \\
\hline Sheep-1 & 0.989 & 0.987 & 0.991 & ID & 1 & 0.998 & 0.983 & 0.979 & 0.976 & 0.973 & 0.967 & 0.937 & 0.952 & 0.954 \\
\hline Sheep-2 & 0.987 & 0.988 & 0.986 & 1 & ID & 0.999 & 0.985 & 0.981 & 0.978 & 0.981 & 0.966 & 0.934 & 0.958 & 0.959 \\
\hline Sheep-3 & 0.991 & 0.986 & 0.993 & 0.998 & 0.999 & ID & 0.980 & 0.983 & 0.969 & 0.980 & 0.964 & 0.929 & 0.961 & 0.962 \\
\hline FN598874-Germany & 0.953 & 0.950 & 0.957 & 0.983 & 0.985 & 0.980 & ID & 0.986 & 0.992 & 0.991 & 0.985 & 0.983 & 0.976 & 0.984 \\
\hline CP003476-USA & 0.962 & 0.966 & 0.964 & 0.979 & 0.981 & 0.983 & 0.986 & ID & 0.990 & 0.993 & 0.984 & 0.979 & 0.980 & 0.983 \\
\hline DQ462665-Iran & 0.932 & 0.936 & 0.932 & 0.976 & 0.978 & 0.969 & 0.992 & 0.990 & ID & 1 & 0.982 & 0.969 & 0.983 & 0.986 \\
\hline GU445163-Iran & 0.941 & 0.940 & 0.944 & 0.973 & 0.981 & 0.980 & 0.991 & 0.993 & 1 & ID & 0.985 & 0.970 & 0.986 & 0.989 \\
\hline M60398-France & 0.928 & 0.929 & 0.930 & 0.967 & 0.966 & 0.964 & 0.985 & 0.984 & 0.982 & 0.985 & ID & 0.975 & 0.990 & 0.991 \\
\hline NC017361-S Africa & 0.920 & 0.918 & 0.916 & 0.937 & 0.934 & 0.929 & 0.983 & 0.979 & 0.969 & 0.970 & 0.975 & ID & 0.993 & 0.989 \\
\hline DQ141576-China & 0.926 & 0.924 & 0.922 & 0.952 & 0.958 & 0.961 & 0.976 & 0.980 & 0.983 & 0.986 & 0.990 & 0.993 & ID & 0.994 \\
\hline AB664954-Japan & 0.926 & 0.923 & 0.923 & 0.954 & 0.959 & 0.962 & 0.984 & 0.983 & 0.986 & 0.989 & 0.991 & 0.989 & 0.994 & ID \\
\hline
\end{tabular}




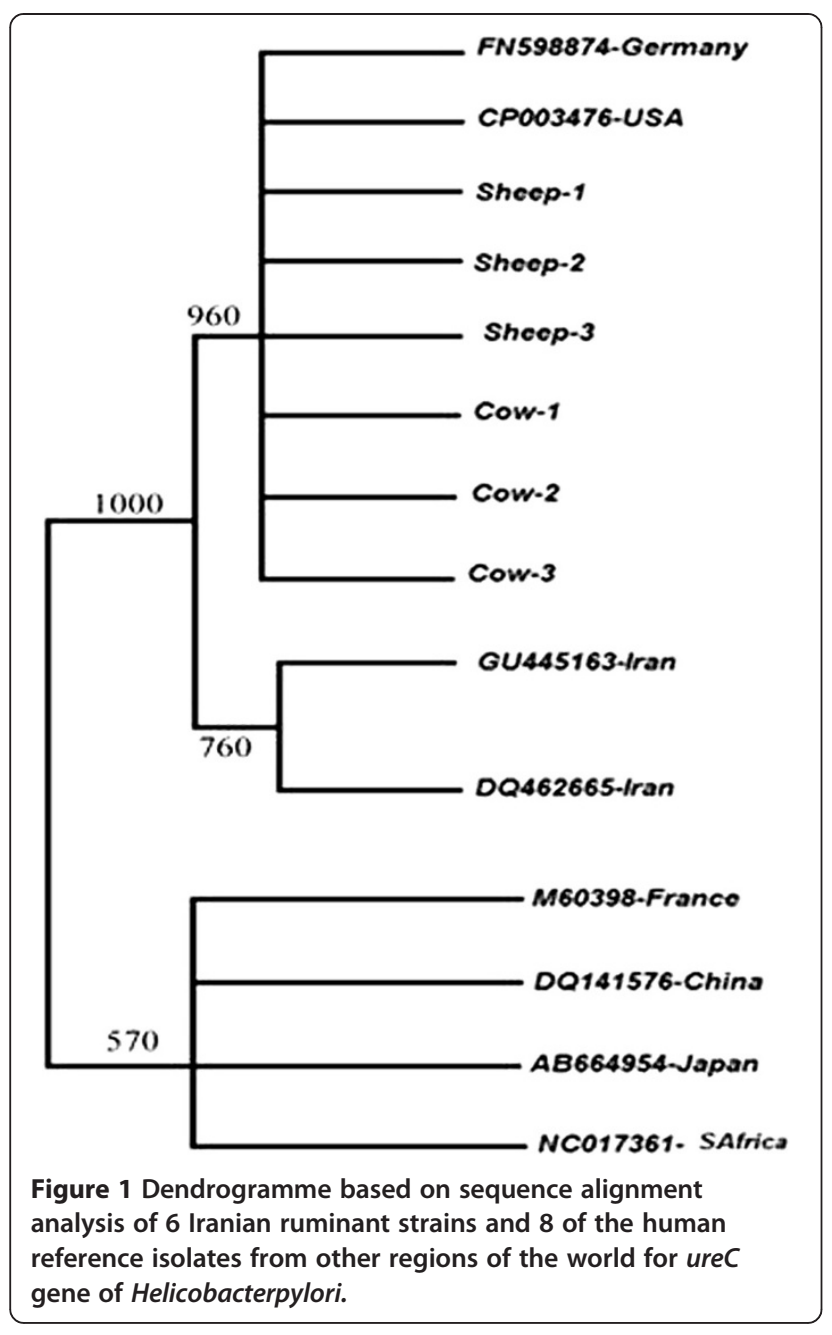

and humans. The rate of homology was low between cow and sheep too. Since considerable number of studied sheep carried $H$. pylori without any pathological evidence, it seems that sheep may are natural host for H. pylori. Besides DNA sequence homology among sheep and human $H$. pylori strains suggest that sheep may serve as a reservoir for this bacteria. Our findings are consistent with Dore et al. study which has hypothesized sheep is the ancestor host of H. pylori [4]. Although high prevalence of H. pylori among human population in comparison with other mammalian, indicating $H$. pylori is more adapted to human body, the main role of sheep in $H$. pylori evolution story is supported by our study in company with some other studies. Dore et al. showed that nearly all of Sardinian shepherds carried $H$. pylori. Morris et al. has reported the higher prevalence of antibodies against $H$. pylori in abattoir workers, such as veterinarians, butchers, and slaughterers [28]. Mégraud and Broutet study showed a number of animals, mostly living in human environment, had H. pylori in their stomach and therefore to be involved in the transmission of this bacterium [29]. Some other reports also support zoonotic transmission of $H$. pylori via close contact with domestic animals [4,30-33]. These studies, along with those have been shown that $H$. pylori can survive in sheep milk $[4,19,34-36]$ are supportive for reservoir role of sheep for human infection. Due to lack of any recorded sequence for $H$. pylori with animal source in Gene bank, we compared our isolates sequences with recorded human isolates sequences. Despite the little diversity in studied sequences, we were able to justify the genetic diversity of the bacterium based on its diverse hosts. As the origin of many Iranian noble cows and sheep refer to the America and Germany, so the perceived genetic similarities among sequences of H. pylori FN598874Germany and CP003476-USA with those of Iranian cow and sheep isolates in this research can justify this claim. On the other hand, transportation of livestock between Far-East Countries (Japan and China) and South Africa and Iran basically does not have historical background [37]. Thus, placing of Japanese, Chinese and South Africans strains in other branches of phylogenetic tree is indicating more differences in the sequence of $H$. pylori between Iran and mentioned countries.

\section{Conclusion}

In conclusion cows and sheep in Iran harbor H. pylori in their gastric tissue similar in genotype of the cagA and $v a c A$ allels with isolates recovered from human. Also since there was a high homology sequence of $H$. pylori DNA among sheep and human, suggest that sheep may are the natural reservoir of the bacteria and can transmit H. pylori to human community.

\section{Competing interests}

The authors declare that they have no competing interests.

Authors' contributions

The DNA extraction, PCR techniques and supporting of project were performed by HM and HD. MG collected the Samples, Statistical analysis and writing of manuscript were performed by NS, All authors read and approved the final manuscript.

\section{Acknowledgment}

The authors would like to thank Mr. M. Momeni, Dr. Sh. Nejat, and Mr. Gh. Ramezani at the Biotechnology Research Center of the Islamic Azad University of Shahrekord and Endoscopy Unit of Hajar Hospital of Shahrekord, for their sincere technical and clinical support.

\section{Author details}

${ }^{1}$ Department of Microbiology, Faculty of Veterinary Medicine, ShahreKord Branch, Islamic Azad University, ShahreKord, Iran. ²Department of Medical Microbiology, Faculty of Medicine, Shahid Beheshti University of Medical Science, Tehran, Iran. ${ }^{3}$ Young Researchers and Elite club, Central Tehran Branch, Islamic Azad University, P.O.Box: 13185-768, Tehran, Iran. ${ }^{4}$ Graduated of Veterinary Medicine, Faculty of Veterinary Medicine, ShahreKord Branch, Islamic Azad University, ShahreKord, Iran.

Received: 11 August 2013 Accepted: 21 March 2014 Published: 3 April 2014 


\section{References}

1. Kargar M, Souod N, Ghorbani-Dalini S, Doosti A, Rezaian AA: Evaluation of cagA tyrosin phosphorylation DNA motifs in Helicobacter pylori isolates from gastric disorder patients in west of Iran. Sci Res Essays 2011. 6:6454-6458.

2. Momtaz H, Souod N, Dabiri H: Comparison of the virulence factors of Helicobacter pylori isolated in stomach and saliva in Iran. Am J Med SCi 2010, 340:345-349.

3. Tabatabaei M: Application of molecular and central cultural methods for identification of Helicobacter spp in different animal sources. Global Vet 2012, 8:292-297.

4. Dore MP, Sepulveda AR, El-Zimaity H, Yamaoka Y, Osato MS, Mototsugu K, Nieddu AM, Realdi G, Graham DY: Isolation of Helicobacter pylori from sheep-implications for transmission to humans. Am J Gastroenterol 2001, 96:1396-1401.

5. Mohamed AA, El- Gohari AH: Epidemiological aspects of Helicobacter pylori infections as an emergence zoonotic disease: Animal reservoirs and public health implications (A review article). 7th Int Sci Conf, MANSOURA 2012:17-25.

6. Husson MO, Vincent P, Grabiaud MH, Furon D, Leclerc H: Anti-Helicobacter pylori lgG levels in abattoir workers. Gastroenterol Clin Biol 1991, 15:723-726

7. Kolodzieyski L, Kim B, Park H, Yoon HS, Lim CW: Prevalence of gastrospirillum-like organisms in pigs, cattle, and dogs: a comparison of diagnostic methods between species. Vet Med 2008, 53:193-202.

8. Quaglia NC, Dambrosio A, Normanno G, Parisi A, Patrono R, Ranieri G, Rella A, Celano GV: High occurrence of Helicobacter pylori in raw goat, sheep and cow milk inferred by glmM gene: a risk of food-borne infection?Int J. Food Microbiol 2008, 124:43-47.

9. Kargar M, Ghorbani-Dalini S, Doosti A, Souod N: Real-time PCR for Helicobacter pylori quantification and detection of clarithromycin resistance in gastric tissue from patients with gastrointestinal disorders. Res Microbiol 2012, 163:109-113.

10. Yamaoka Y: Roles of the plasticity regions of Helicobacter pylori in gastroduodenal pathogenesis. J Med Microbiol 2008, 57:545-553.

11. Momtaz H, Souod N, Dabiri H, Sarshar M: Study of Helicobacter pylori genotype status in saliva, dental plaques, stool and gastric biopsy samples. World I Gastroenterol 2012, 18:2105-2111.

12. Jafari F, Shokrzadeh L, Dabiri H, Baghaei K, Yamaoka Y, Zojaji H, Haghazali M, Molaei M, Zali MR: vacA genotypes of Helicobacter pylori in relation to cagA status and clinical outcomes in Iranian populations. Jpn J Infect Dis 2008, 61:290-293.

13. Argent RH, Thomas RJ, Letley DP, Rittig MG, Hardie KR, Atherton JC: Functional association between the Helicobacter pylori virulence factors VacA and CagA. J Med Microbiol 2008, 57:145-150.

14. Torres LE, Melián $K$, Moreno A, Alonso J, Sabatier CA, Hernández M, Bermúdez L, Rodríguez BL: Prevalence of vacA, cagA and babA2 genes in Cuban Helicobacter pylori isolates. World J Gastroenterol 2009, 15:204-210.

15. Yamazaki S, Yamakawa A, Okuda T, Ohtani M, Suto H, Ito Y, Yamazaki Y, Keida Y, Higashi H, Hatakeyama M, Azuma T: Distinct diversity of vacA, cagA, and cagE genes of Helicobacter pylori associated with peptic ulcer in Japan. J Clin Microbiol 2005, 43:3906-3916.

16. Wang J, Chi DS, Laffan JJ, Li C, Ferguson DA Jr, Litchfield P, Thomas E: Comparison of cytotoxin genotypes of Helicobacter pylori in stomach and saliva. Dig Dis Sci 2002, 47:1850-1856.

17. Solnick JV, Schauer DB: Emergence of diverse Helicobacter species in the pathogenesis of gastric and enterohepatic diseases. Clin Microbiol Rev 2001, 14:59-97.

18. Farshad S, Japoni A, Alborzi A, Zarenezhad M, Ranjbar R: ChangingprevalenceofHelicobacter pylori in southof Iran. Iranian J Clin Infect Dis 2010, 5:65-69.

19. Rahimi E, Kheirabadi EK: Detection of Helicobacterpylori in bovine, buffalo, camel, ovine, and caprine milk in Iran. Foodborne Pathog Dis 2012, 9:453-456.

20. Fujimura S, Kawamura T, Kato S, Tateno H, Watanabe A: Detection of Helicobacter pylori in cow's milk. Lett App/ Microbiol 2002, 35:504-507.

21. Hunt RH, Xiao SD, Megraud F, Leon-Barua R, Bazzoli F, van der Merwe S, Vaz Coelho LG, Fock M, Fedail S, Cohen H, Malfertheiner P, Vakil N, Hamid S, Goh KL, Wong BC, Krabshuis J, Le Mair A: Helicobacter pylori in developing countries: world gastroenterology organisation global guideline.

J Gastrointestin Liver Dis 2011, 20:299-304.
22. Javed M, Amin K, Muhammad D, Husain A, Mahmood N: Prevalence of H. Pylori. Professional Med Sep 2010, 17:431-439.

23. Gueneau P, Fuenmayor J, Aristimuño OC, Cedeño S, Báez E, Reyes N, Michelangeli F, Domínguez-Bello MG: Are goats naturally resistant to gastric Helicobacter infection? Vet Microbiol 2002, 84:115-121.

24. Albert MJ, Al-Akbal HM, Dhar R, De R, Mukhopadhyay AK: Genetic affinities of Helicobacter pylori isolates from ethnic Arabs in Kuwait. Gut Pathog 2010, 2:6.

25. Zhang Z, Zheng Q, Chen X, Xiao S, Liu W, Lu H: The Helicobacter pylori duodenal ulcer promoting gene, dupA in China. BMC Gastroenterol 2008, 8:49.

26. Homan M, Luzar B, Kocjan BJ, Orel R, Mocilnik T, Shrestha M, Kveder M, Poljak M: Prevalence and clinical relevance of $\operatorname{cagA}$, vacA, and iceA genotypes of Helicobacter pylori isolated from Slovenian children. J Pediatr Gastroenterol Nutr 2009, 49:289-296.

27. Miernyk K, Morris J, Bruden D, McMahon B, Hurlburt D, Sacco F, Parkinson A, Hennessy T, Bruce M: Characterization of Helicobacter pylori cagA and vacA genotypes among Alaskans and their correlation with clinical disease. J Clin Microbiol 2011, 49:3114-3121.

28. Morris A, Nicholson G, Lloyd G, Haines D, Rogers A, Taylor D: Seroepidemiology of Campylobacter pyloridis. NZ Med J 1986, 99:657-659.

29. Mégraud F, Broutet N: Have we found the source of Helicobacter pylori? Aliment Pharmacol Ther 2000, 14(Suppl 3):7-12.

30. Vaira D, Ferron P, Negrini R, Cavazzini L, Holton J, Ainley C, Londei M, Vergura M, Dei R, Colecchia A: Detection of Helicobacter pylori-like organisms in the stomach of some food-source animals using a monoclonal antibody. Ital J Gastroenterol 1992, 24:181-184.

31. Fox JG: Non-human reservoirs of Helicobacter pylori. Aliment Pharmacol Ther 1995, 9(Suppl. 2):93-103.

32. Safaei GH, Rahimi E, Zandib A, Rashidipour A: Helicobacter pylori as a zoonotic infection: the detection of $H$. pylori antigens in the milk and faeces of cows. JRMS 2011, 16(2):184-187.

33. Dunn BE, Cohen H, Blaser MJ: Helicobacter pylori. Clin Microbiol Rev 1997 , 10:720-741

34. Dore MP, Bilotta M, Vaira D, Manca A, Massarelli G, Leandro G, Atzei A Pisanu G, Graham DY, Realdi G: High prevalence of helicobacter pylori infection in shepherds. Dig Dis Sci 1999, 44(6):1161-1164.

35. Turutoglu $\mathrm{H}$, Mudul $\mathrm{S}$ : Investigation of helicobacter pylori in raw sheep milk samples. J Vet Med B Infect Dis Vet Public Health 2002, 49(6):308-309.

36. Quaglia NC, Dambrosio A, Normanno G, Parisi A, Patrono R, Ranieri G, Rella A, Celano GV: High occurrence of helicobacter pylori in raw goat, sheep and cow milk inferred by glmM gene: a risk of food-borne infection? Int J Food Microbiol 2008, 124(1):43-47.

37. Rahman $S A$, Walker $\mathrm{L}$, Ricketts W: Global perspectives on animal welfare: Asia, the Far East, and Oceania. Rev Sci Tech 2005, 24:597-612.

doi:10.1186/1471-230X-14-61

Cite this article as: Momtaz et al: Study of Helicobacter pylori genotype status in cows, sheep, goats and human beings. BMC Gastroenterology 2014 14:61.

\section{Submit your next manuscript to BioMed Central and take full advantage of:}

- Convenient online submission

- Thorough peer review

- No space constraints or color figure charges

- Immediate publication on acceptance

- Inclusion in PubMed, CAS, Scopus and Google Scholar

- Research which is freely available for redistribution 